FREEDOM COLONIES 
NUMBER FIFTEEN

Jack and Doris Smothers Series in Texas History, Life, and Culture 


\section{Freecolom Colomies}

I NDEPENDENT BLACK TEXANS IN THE TIME OF JIM CROW BY THAD SITTON AND JAMES H. CONRAD With research assistance and photographs by Richard Orton

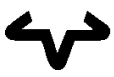
UNIVERSITY OF TEXAS PRESS Austin 


\section{Copyright (C) 2005 by the University of Texas Press \\ All rights reserved \\ Printed in the United States of America \\ First edition, 2005}

Requests for permission to reproduce material from this work should be sent to Permissions, University of Texas Press, P.O. Box 7819, Austin, TX 78713-7819.

\section{$(\infty)$}

The paper used in this book meets the minimum requirements of ANSI/NISO Z39.48-I992 (RI997) (Permanence of Paper).

Sitton, Thad, I94I-

Freedom colonies : independent Black Texans in the time of

Jim Crow / by Thad Sitton and James H. Conrad.

p. $\quad$ cm. - (Jack and Doris Smothers series in

Texas history, life, and culture ; no. I5)

Includes bibliographical references and index.

Is в N 0-292-706I8-9 (cl. : alk. paper) - Is в N о-292-70642-I (pbk. : alk. paper)

I. Freedmen-Texas-History. 2. African American farmers-Texas-History.

3. African Americans-Land tenure-Texas-History. 4. African Americans-

Texas-Economic conditions. 5. Agricultural colonies-Texas-History. 6. Land settlement-Texas-History. 7. Texas-History-I846-I950. 8. Texas-Race relations. 9. Texas-Economic conditions.

I. Conrad, James H. II. Title. III. Series.

EI85.93.T4S47 2004

333.33 '5'089960730794-dc22 2004009477 
Black people had carved their autonomy from "free spaces," weak points in a white power structure that whites had not shored up yet, places where whites were not looking, sites that had not yet become important enough to the preservation of privilege that whites cared what Blacks did there.

\section{- DEBORAH J. HOSKINS}

Then it dawned upon me with a certain suddenness that I was different from the others; or like, mayhap, in heart and life and longing, but shut out from their world by a vast veil. I had thereafter no desire to tear down that veil, to creep through; I held all beyond it in common contempt, and lived above it in a region of blue sky and great wandering shadows.

-W. E. B. DU BOIS 
THIS PAGE INTENTIONALLY LEFT BLANK 